\title{
Growth, carcass and sensory characteristics of m. longissimus lumborum from wethers fed silage diets made from maize or various sorghum varieties
}

\author{
M.J.C. Bosman $^{* a}$, E.C. Webb ${ }^{\text {b }}$, H.J. Cilliers ${ }^{\mathrm{c}} \&$ H.S. Steyn ${ }^{\mathrm{d}}$ \\ ${ }^{\mathrm{a} D e p a r t m e n t ~ o f ~ N u t r i t i o n, ~ a n d ~}{ }^{\mathrm{d} S t a t i s t i c a l ~ C o n s u l t a t i o n ~ S e r v i c e, ~ P o t c h e f s t r o o m ~ U n i v e r s i t y ~ f o r ~ C h r i s t i a n ~ H i g h e r ~ E d u c a t i o n, ~}$ \\ Potchefstroom 2520, South Africa; ${ }^{b}$ Department of Animal and Wildlife Science, University of Pretoria, Pretoria 0002, South \\ Africa; ' Department of Agricultural Development, North West Agricultural Development Institute, Potchefstroom 2520, \\ South Africa
}

\begin{abstract}
Growth, carcass characteristics and eating quality of meat from South African Mutton Merino wethers fed maize or different sorghum silage diets were studied. Forty newly weaned wethers $(20 \mathrm{~kg})$ were randomly allocated to 10 dietary treatments, viz. non-bird-resistant grain sorghum silage (NGS), maize silage (MS), bird-resistant grain sorghum silage (BGS), forage sorghum silage (FSS) and a standard non-silage control diet consisting of equal proportions of maize meal and milled lucerne hay (C). Silage was included at 2 levels, namely $50 \%$ or $70 \%$ of the total diet on dry matter basis. Average daily gains of wethers were recorded from weaning to slaughter at $45 \mathrm{~kg}$ live mass. Carcass mass, dressing percentage, subcutaneous fat thickness and carcass length were recorded. Samples from the left $m$. longissimus lumborum were minced and stewed to determine foreign odours and flavours, while samples from the right $\mathrm{m}$. longissimus lumborum were oven-roasted for subsequent sensory evaluation by an analytical sensory panel. Growth responses did not differ between wethers fed MS, NGS or BGS at inclusion levels of $50 \%$ or $70 \%$. FSS at the $70 \%$ inclusion level resulted in poorer growth rates $(p<0.05)$ and longer feeding periods $(p<0.05)$ compared to the other silage diets. The best feed conversion efficiencies and shortest finishing periods were recorded by feeding MS at either the $50 \%$ or the $70 \%$ inclusion level, NGS at the $50 \%$ inclusion level, or BGS at the 50\% inclusion level. Dressing percentages and subcutaneous fat thicknesses of wethers fed BGS and FSS at a $70 \%$ inclusion level were lower $(p<0.05)$ compared to those fed the other silage diets. No significant differences in sensory characteristics or cooking losses and no sensory defects were observed among wethers fed different silage diets.
\end{abstract}

Keywords : Wethers, growth, carcass characteristics, sensory characteristics, maize silage, sorghum silage *Author to whom correspondence should be addressed, E-mail: vgehl@ puknet.puk.ac.za

\section{Introduction}

Maize (Zea mays) and grain sorghum (Sorghum vulgare) crops are produced successfully in the summerrainfall areas of South Africa, and both are suitable for silage production (Agricultural Development Program, 1986). However, limited information has been published on the feeding of maize and sorghum silage to weaned lambs (Boshoff et al., 1980). The potential of alternative feedstuffs to overwinter weaned lambs in the southern region of the North West Province of South Africa has been investigated. This region is characterized by a relatively low and variable rainfall pattern during summer and a lack of nutritious forage resources during winter. Reyneke (1967) suggested that an autumn lambing season would be more advantageous in this region than a spring lambing season, mainly due to the lower internal parasite burden in autumn. Therefore, this practice would be particularly feasible if silage diets could be used during the autumn and winter months. Although maize silage has excellent ensiling characteristics, a high dry matter yield and a high digestibility, it requires more water per unit dry matter produced than sorghum (Meeske et al., 1993). Sorghum is not only more drought resistant than maize, but becomes dormant during periods of water shortage and resumes growth upon receiving sufficient rain again (Morrison, 1957). According to Paul et al. (1981) many researchers have investigated the effect of nutrition on carcass characteristics of lambs, but few have paid attention to the effect of dietary factors on the eating quality and cooking losses of the meat. It has been found that the type of diet can affect the eating quality of lamb (Bosman et al., 1993 \& 1994; Webb et al., 1994, 1997 \& 1999), and can be the cause of foreign odours and flavours (generally referred to as "taints") in the meat (Cramer et al., 1967). Field et al. (1978) detected an increased flavour intensity in meat of animals consuming a pure maize silage diet compared to meat from animals where the silage was partially replaced by maize meal. Field et al. (1983) also reported a pork taint in meat from lambs finished on maize silage diets. Whether the feeding of sorghum silage to lambs would affect the eating quality of their meat has apparently not being 
established. Therefore, the present study was conducted to determine the effect of maize and different sorghum silage diets on the growth, carcass quality and sensory quality characteristics of $m$. longissimus lumborum from wethers.

\section{Materials and methods}

Forty South African Mutton Merino wethers (mass: $20 \mathrm{~kg}$ ) were randomly allocated to 10 dietary treatments with four animals per treatment.The experimental animals were housed in individual pens. Dietary treatments were non-bird-resistant grain sorghum silage (NGS), maize silage (MS), bird-resistant grain sorghum silage (BGS) and forage sorghum silage (FSS). A standard non-silage control consisting of equal proportions of maize meal and milled lucerne hay $(\mathrm{C})$ was included for sensory evaluation purposes only. The diets were supplemented with concentrate at two levels, viz. $50 \%$ and $70 \%$ ( 5 diets $\times 2$ concentrate levels $=10$ dietary treatments $\mathrm{x} 4$ animals per treatment). The concentrate consisted of a mixture of high protein concentrate (HPC) and maize meal to provide a crude protein concentration of $14 \%$ for the total diet for the period from weaning to $30 \mathrm{~kg}$ live mass and $11 \%$ for the period from $30 \mathrm{~kg}$ to slaughter mass. During the adaptation period of 21 days, silage was provided ad libitum. The proportion of silage fed was gradually decreased to either $70 \%$ or $50 \%$, while the proportion of concentrate was increased from $0 \%$ to either $30 \%$ or $50 \%$ of the total diet on a dry matter basis respectively. Wethers had ad libitum access to these diets until a target slaughter mass of $45 \mathrm{~kg}$ was reached. All wethers were fasted for 18 hours and slaughtered by severing the jugular vein. Carcasses were not electrically stimulated, but were matured for 5 days at $2{ }^{\circ} \mathrm{C}$. Samples of the left and right $m$. longissimus lumborum (loin samples) were taken from all lambs per group, vacuum packed, labelled and frozen at $-70{ }^{\circ} \mathrm{C}$.

Initial and slaughter masses were recorded after a fasting period of 18 hours. The feed intake of each wether was recorded daily and both feed conversion efficiency and average daily gain calculated at the end of the trial. Cold carcass mass was determined after cooling for 24 hours at $4{ }^{\circ} \mathrm{C}$. Carcass length was taken as the distance from the anterior end of the first cranial rib to the middle of the pelvic symphysis. The mean subcutaneous fat thickness was determined by three measurements taken at a point over the 13th rib, approximately $25 \mathrm{~mm}$ from the midline.

One pair of loin samples per dietary treatment was defrosted to an internal temperature of $2-5{ }^{\circ} \mathrm{C}$ in a refrigerator 72 hours before each evaluation session. Once defrosted, the cuts were removed from the vacuum packaging and all hard intestinal fat removed. Each right loin was weighed to calculate its cooking period using the following formula: $30 \mathrm{~min}$ per $500 \mathrm{~g}+20 \mathrm{~min}$ (Bosman et al., 1993). The left loin of each lamb was minced and examined for possible foreign odours and flavours. Since foreign odours and flavours could be present in fat (Sink \& Caporaso, 1977), both fat and meat were removed from the bone and minced together. Individual $500 \mathrm{~g}$ samples were coded, labelled and stored overnight in plastic bags at $1^{\circ} \mathrm{C}$.

For each evaluation session five minced samples from the left loin were stewed for 45 minutes in separate 2litre saucepans fitted with hollow lids. Boiling distilled water was added in the ratio of $25 \mathrm{ml}$ per $100 \mathrm{~g}$ mince. To retain volatile odours and flavours the samples were stewed slowly in closed saucepans and only stirred occasionally to avoid compaction. The samples were served directly from the saucepans in order to ensure effective evaluation of foreign odours. Samples from the right loin were roasted at $160{ }^{\circ} \mathrm{C}$ on a rack in a roasting pan with the fat layer uppermost in an oven (Defy 420D), until an internal endpoint temperature of $70{ }^{\circ} \mathrm{C}$ (Electronic Ama-Digit ET thermometer) was reached. After roasting each sample was removed from the oven, weighed and the m. longissimus lumborum was removed from the bone after 10-minutes. Because the typical lamb aroma and flavour is also associated with fat, the subcutaneous fat was retained in the sample presented for evaluation by the sensory panel.

In order to ensure that the sensory panel room remained relatively free from food odours, the minced samples were served in 2-litre saucepans with hollow lids on two prepared tables on an adjoining veranda in front of the sensory panel room. The sensory panel leader lifted the lid of each sample so that the steam could escape (as a precaution against scalding) before the panel members were allowed to evaluate the odour of the loin samples. The sensory panel evaluated every sample for the presence of foreign odours by deeply inhaling the vapours and specifically smelling the vapours which had collected in the hollow of the lid, and noting their conclusions on the score sheets. After this, $15 \mathrm{ml}$ of each sample was placed into lukewarm coded porcelain bowls in a random order and served in sensory panel cubicles for evaluation of the presence or absence of foreign flavours.

Six $5 \mathrm{~mm}$-thick slices were cut from the caudal halves of each oven-roasted loin sample. The sensory samples were placed in lukewarm, coded, white porcelain bowls and covered with aluminium foil to prevent loss of aroma, drying and cooling so that the samples could be served warm to the sensory panel members (Bosman et al., 1993 \& 1994). Each panellist received five bowls on a white plate during the session.

Four evaluation sessions were conducted on the same day once per week. Each consisted of two series of five mince samples followed by five oven-roasted samples, with a break of 30 minutes between each session. This procedure was repeated for four weeks. Panel members were screened and trained according to procedures outlined 
by the AMSA (1978) and Cross et al. (1978). The eating quality characteristics of lamb samples were evaluated by a 6-member trained, analytical sensory panel using a category scaling test with a 1-8 point Likert-type measuring scale. The sensory quality attributes evaluated were tenderness, juiciness, flavour and the presence of foreign odours and flavours. A value of 1 indicated the minimum (negative) and 8 the maximum (positive) presence of any characteristic, except in the case of foreign odour and flavour, where 8 indicated the absence of any taint. The criteria for sensory evaluation, as well as accompanying explanations, were presented to the sensory panel members during every session together with the evaluation form so that there could be no uncertainty regarding the meaning of the values allocated.

Samples for shear force testing were cut from the right side of each m. longissimus lumborum. A WarnerBratzler shearing device was used to determine the shear force required to cut through a cylindrical core $(\varnothing 12.5 \mathrm{~mm})$ of cooked meat that had been cooled overnight $\left(15^{\circ} \mathrm{C}\right)$ (Naudé, 1972). Samples for shear force evaluation were cut perpendicular to the grain of the meat. Ten measurements were carried out on each sample and from these values the mean shear force resistance ( $\mathrm{kg}$ force) per sample was calculated. The higher the reading recorded, the greater the shear force required to cut through the meat and therefore the tougher the meat.

Differences between the means of dietary treatments and silage levels were tested by means of two-way analyses of variance of growth performance, carcass traits and the sensory and cooking loss data. This was followed by multiple comparisons between dietary means using the Tukey-method (Steel and Torrie, 1980) which controls the experiment-wise error rate (in contrast with the least significant difference (LSD)-method, which only controls the comparison-wise error rate). The procedure GLM of SAS (Statistical Analysis Systems, 1985) was used for these computations.

\section{Results and discussion}

Results for the various growth performance characteristics of wethers are given in Table 1. Initial mass and slaughter mass did not differ $(p>0.05)$ between treatments because the wethers were randomly allocated to different dietary treatments and were slaughtered in the weight range of $43-45 \mathrm{~kg}$ live weight.

Table 1. Means ( \pm standard deviations) of growth performance attributes of wethers fed diets containing maize or sorghum silage at inclusion rates of $50 \%$ or $70 \%$.

\begin{tabular}{|c|c|c|c|c|c|c|}
\hline Diet & $\begin{array}{l}\text { Silage } \\
\text { level }\end{array}$ & $\begin{array}{l}\text { Initial } \\
\text { mass } \\
(\mathrm{kg})\end{array}$ & $\begin{array}{l}\text { Slaughter } \\
\text { mass }^{\$} \\
(\mathrm{~kg})\end{array}$ & $\begin{array}{l}\text { Number of } \\
\text { days }\end{array}$ & $\begin{array}{l}\mathrm{FCE}^{\#} \\
(\mathrm{~g} / \mathrm{g})\end{array}$ & $\begin{array}{l}\text { Average daily } \\
\text { gain } \\
\text { (g/lamb/day) }\end{array}$ \\
\hline \multirow{2}{*}{$\begin{array}{l}\text { Non-bird-resistant grain } \\
\text { sorghum silage }+ \\
\text { concentrate }(\mathrm{NGS})\end{array}$} & $50 \%$ & $19.7 \pm 2.6$ & $45.5 \pm 1.3$ & $141.0 \pm 13.0^{\mathrm{a}}$ & $6.33 \pm 0.89^{\mathrm{a}}$ & $182.3 \pm 14.4^{\mathrm{a}}$ \\
\hline & $70 \%$ & $18.7 \pm 1.6$ & $44.8 \pm 1.0$ & $177.0 \pm 23.0^{\mathrm{ab}}$ & $7.18 \pm 0.21^{\mathrm{ab}}$ & $149.0 \pm 16.6^{\mathrm{ab}}$ \\
\hline \multirow{2}{*}{$\begin{array}{l}\text { Maize silage + } \\
\text { concentrate (MS) }\end{array}$} & $50 \%$ & $18.9 \pm 2.3$ & $45.0 \pm 0.5$ & $164.0 \pm 31.0^{\mathrm{a}}$ & $6.19 \pm 0.42^{\mathrm{a}}$ & $161.0 \pm 18.9^{\mathrm{ab}}$ \\
\hline & $70 \%$ & $19.8 \pm 2.9$ & $44.3 \pm 1.0$ & $162.0 \pm 32.0^{\mathrm{a}}$ & $6.26 \pm 0.43^{\mathrm{a}}$ & $154.0 \pm 23.5^{\mathrm{ab}}$ \\
\hline \multirow{2}{*}{$\begin{array}{l}\text { Bird-resistant grain } \\
\text { sorghum silage }+ \\
\text { concentrate }(\mathrm{BGS})\end{array}$} & $50 \%$ & $19.8 \pm 1.3$ & $45.3 \pm 0.9$ & $159.0 \pm 25.0^{\mathrm{a}}$ & $6.74 \pm 0.57^{\mathrm{a}}$ & $163.3 \pm 23.7^{\mathrm{a}}$ \\
\hline & $70 \%$ & $19.3 \pm 2.8$ & $44.3 \pm 2.1$ & $184.0 \pm 29.0^{\mathrm{ab}}$ & $7.46 \pm 0.98^{\mathrm{ab}}$ & $138.5 \pm 24.8^{\mathrm{ab}}$ \\
\hline \multirow{2}{*}{$\begin{array}{l}\text { Forage sorghum silage + } \\
\text { concentrate (FSS) }\end{array}$} & $50 \%$ & $19.2 \pm 1.8$ & $45.0 \pm 1.3$ & $191.0 \pm 17.0^{\mathrm{ab}}$ & $7.38 \pm 0.72^{\mathrm{ab}}$ & $136.3 \pm 16.4^{\mathrm{ab}}$ \\
\hline & $70 \%$ & $18.8 \pm 2.3$ & $44.0 \pm 1.2$ & $227.0 \pm 53.0^{\mathrm{b}}$ & $8.67 \pm 1.85^{\mathrm{b}}$ & $116.3 \pm 33.9^{\mathrm{b}}$ \\
\hline
\end{tabular}

\footnotetext{
ab Means in the same row without a common superscript differ significantly $(p<0.05)$; ${ }^{\$}$ Initial and slaughter masses were recorded after a fasting period of 18 hours; ${ }^{*}$ Feed conversion efficiency
}

Wethers fed FSS at a 70\% inclusion level required longer finishing periods $(p<0.05)$ and had higher feed conversion ratios $(p<0.05)$ compared to those fed NGS, MS and BGS at the 50\% inclusion level and MS at the $70 \%$ inclusion level. Average daily gains of wethers fed silage diets at a 50\% inclusion level were numerically, but 
not statistically, higher than those fed silage diets at a 70\% inclusion level (Table 1). Wethers fed NGS at a $50 \%$ inclusion level achieved the highest average daily gains $(182.3 \pm 14.4 \mathrm{~g} / \mathrm{d})$, while those fed MS and BGS appeared to be intermediate and those fed FSS at a 70\% inclusion rate were the lowest. The average daily gains of wethers in the present study generally agree with that (194 g/d) reported by Webb (1992) for SA Mutton Merino wethers fed a diet with similar maize content. The wethers fed FSS at a 70\% inclusion level had a significantly slower rate of gain $(p<$ 0.05 ) compared to those fed NGS at a 50\% inclusion level. No significant differences in average daily gains were recorded between wethers fed different silage diets at a 50\% inclusion level.

Carcass characteristics are presented in Table 2. The average dressing percentage and fat thickness recorded in the present study agree with previous results of SA Mutton Merino wethers in the same weight range (Webb, 1992; Webb et al., 1999). Carcass characteristics of wethers fed at the 50\% silage level did not differ significantly between dietary treatments $(p<0.05)$. In contrast, some carcass characteristics were influenced by dietary treatments at the $70 \%$ silage level. Wethers fed NGS and MS yielded significantly heavier carcasses compared to those fed BGS or FSS $(p<0.05)$, mainly due to higher dressing percentages $(p<0.05)$. Lambs fed NGS attained a significantly higher subcutaneous fat thickness $(p<0.05)$ than those fed either BGS or FSS. Differences in carcass length were not statistically significant.

Table 2 Means ( \pm standard deviations) for carcass characteristics of wethers fed diets containing maize or sorghum silage at inclusion rates of $50 \%$ or $70 \%$.

\begin{tabular}{|c|c|c|c|c|c|}
\hline Diet & $\begin{array}{l}\text { Silage } \\
\text { level }\end{array}$ & $\begin{array}{l}\text { Carcass mass } \\
(\mathrm{kg})\end{array}$ & $\begin{array}{l}\text { Dressing } \\
\text { percentage } \\
(\%)\end{array}$ & $\begin{array}{l}\text { Fat thickness } \\
(\mathrm{mm})\end{array}$ & $\begin{array}{l}\text { Carcass length } \\
(\mathrm{mm})\end{array}$ \\
\hline \multirow{2}{*}{$\begin{array}{l}\text { Non-bird-resistant grain } \\
\text { sorghum silage }+ \\
\text { concentrate (NGS) }\end{array}$} & $50 \%$ & $21.6 \pm 1.3^{\mathrm{a}}$ & $47.4 \pm 2.4^{\mathrm{a}}$ & $4.9 \pm 1.2^{\mathrm{ab}}$ & $107.3 \pm 1.0$ \\
\hline & $70 \%$ & $21.5 \pm 0.8^{\mathrm{a}}$ & $48.0 \pm 1.5^{\mathrm{a}}$ & $6.1 \pm 0.4^{\mathrm{a}}$ & $109.5 \pm 3.0$ \\
\hline \multirow{2}{*}{$\begin{array}{l}\text { Maize silage }+ \\
\text { concentrate (MS) }\end{array}$} & $50 \%$ & $21.8 \pm 0.6^{\mathrm{a}}$ & $48.6 \pm 1.6^{\mathrm{a}}$ & $5.2 \pm 0.3^{\mathrm{ab}}$ & $109.3 \pm 1.0$ \\
\hline & $70 \%$ & $20.9 \pm 0.4^{\mathrm{ab}}$ & $47.3 \pm 1.3^{\mathrm{a}}$ & $4.7 \pm 0.9^{\mathrm{ab}}$ & $109.3 \pm 2.4$ \\
\hline \multirow{2}{*}{$\begin{array}{l}\text { Bird-resistant grain } \\
\text { sorghum silage }+ \\
\text { concentrate (BGS) }\end{array}$} & $50 \%$ & $21.3 \pm 0.5^{\mathrm{a}}$ & $47.1 \pm 1.6^{\mathrm{ab}}$ & $3.9 \pm 0.7^{\mathrm{ab}}$ & $110.0 \pm 1.4$ \\
\hline & $70 \%$ & $19.3 \pm 0.6^{\mathrm{bc}}$ & $43.7 \pm 1.4^{\mathrm{bc}}$ & $3.5 \pm 1.4^{\mathrm{b}}$ & $110.3 \pm 1.3$ \\
\hline \multirow{2}{*}{$\begin{array}{l}\text { Forage sorghum silage }+ \\
\text { concentrate } \\
\text { (FSS) }\end{array}$} & $50 \%$ & $20.4 \pm 1.2^{\mathrm{ab}}$ & $45.5 \pm 2.1^{\mathrm{abc}}$ & $4.5 \pm 2.3^{\mathrm{ab}}$ & $111.3 \pm 4.0$ \\
\hline & $70 \%$ & $18.4 \pm 0.8^{c}$ & $41.9 \pm 1.8^{\mathrm{c}}$ & $3.0 \pm 0.6^{\mathrm{b}}$ & $108.0 \pm 2.9$ \\
\hline
\end{tabular}

ab Means in the same row without a common superscript differ significantly $(p<0.05)$

Sensory quality characteristics of $m$. longissimus lumborum samples are given in Table 3; cooking losses and shear force resistance values are summarised in Table 4 . No statistically significant differences $(p>0.05)$ were recorded for any of the sensory quality characteristics or cooking losses. No foreign odours or flavours were detected as a result of feeding maize silage or any of the other silage types. This is in contrast with the results of Field et al. (1983), who reported a pork taint in lamb subsequent to fattening on maize silage diets.

Shear force resistance values were influenced by dietary treatments $(p<0.05)$. The mean shear force resistance values recorded for wethers fed BGS at a 50\% inclusion level and NGS at the 70\% inclusion level were higher $(p<0.05)$ compared to those fed MS, BGS at a 70\% inclusion level, FSS at a 70\% inclusion level or the control diet. Samples from wethers fed FSS at the 50\% inclusion level were also numerically, but not statistically, higher compared to the other silage treatments. 
Table 3 Means ( \pm standard deviations) for sensory quality characteristics of $m$. longissimus lumborum samples from wethers fed diets containing maize or sorghum silage at inclusion rates of $50 \%$ or $70 \%$.

\begin{tabular}{lllllll}
\hline Diet & $\begin{array}{l}\text { Silage } \\
\text { level }\end{array}$ & $\begin{array}{l}\text { Foreign } \\
\text { odour }\end{array}$ & $\begin{array}{l}\text { Foreign } \\
\text { flavour }\end{array}$ & Tenderness & Juiciness & Flavour \\
\hline $\begin{array}{l}\text { Equal proportions of maize meal } \\
\text { and milled lucerne hay (C) }\end{array}$ & $50 \%$ & $8.00 \pm 0.00$ & $8.00 \pm 0.00$ & $7.42 \pm 0.65$ & $7.38 \pm 0.49$ & $7.46 \pm 0.51$ \\
& $70 \%$ & $8.00 \pm 0.00$ & $8.00 \pm 0.00$ & $7.50 \pm 0.59$ & $7.38 \pm 0.49$ & $7.29 \pm 0.55$ \\
$\begin{array}{l}\text { Non-bird-resistant grain } \\
\text { sorghum silage + concentrate } \\
\text { (NGS) }\end{array}$ & $50 \%$ & $8.00 \pm 0.00$ & $8.00 \pm 0.00$ & $7.54 \pm 0.51$ & $7.33 \pm 0.56$ & $7.50 \pm 0.51$ \\
$\begin{array}{l}\text { Maize silage + concentrate } \\
\text { (MS) }\end{array}$ & $50 \%$ & $8.00 \pm 0.00$ & $8.00 \pm 0.00$ & $7.63 \pm 0.49$ & $7.29 \pm 0.46$ & $7.29 \pm 0.55$ \\
& $70 \%$ & $7.88 \pm 0.34$ & $7.92 \pm 0.28$ & $7.71 \pm 0.46$ & $7.29 \pm 0.55$ & $7.46 \pm 0.51$ \\
$\begin{array}{l}\text { Bird-resistant grain sorghum } \\
\text { silage + concentrate (BGS) }\end{array}$ & $50 \%$ & $8.00 \pm 0.00$ & $8.00 \pm 0.00$ & $7.33 \pm 0.48$ & $7.29 \pm 0.55$ & $7.50 \pm 0.59$ \\
& $70 \%$ & $7.92 \pm 0.28$ & $7.92 \pm 0.28$ & $7.54 \pm 0.51$ & $7.42 \pm 0.50$ & $7.42 \pm 0.50$ \\
$\begin{array}{l}\text { Forage sorghum silage + } \\
\text { concentrate (FSS) }\end{array}$ & $50 \%$ & $8.00 \pm 0.00$ & $8.00 \pm 0.00$ & $7.54 \pm 0.51$ & $7.29 \pm 0.62$ & $7.33 \pm 0.56$ \\
& $70 \%$ & $7.88 \pm 0.34$ & $7.92 \pm 0.28$ & $7.67 \pm 0.48$ & $7.46 \pm 0.51$ & $7.21 \pm 0.66$ \\
\end{tabular}

A score of 1 indicated the minimum (intensity) and 8 the maximum (intensity) presence of any characteristic, except in the case of foreign odour and flavour, where 1 indicated very strong taints while 8 indicated the absence of any taints.

Table 4 Means ( \pm standard deviations) for cooking losses and shear force resistance of $m$. longissimus lumborum samples from wethers fed diets containing maize or sorghum silage at inclusion rates of $50 \%$ or $70 \%$.

\begin{tabular}{|c|c|c|c|c|c|}
\hline Diet & $\begin{array}{l}\text { Silage } \\
\text { level }\end{array}$ & $\begin{array}{l}\text { Total } \\
\text { cooking } \\
\text { loss }(\%)\end{array}$ & $\begin{array}{l}\text { Drip loss } \\
(\%)\end{array}$ & $\begin{array}{l}\text { Evaporation } \\
\text { loss } \\
(\%)\end{array}$ & $\begin{array}{l}\text { Shear force } \\
\text { (kg force) }\end{array}$ \\
\hline \multirow{2}{*}{$\begin{array}{l}\text { Equal proportions of maize meal } \\
\text { and milled lucerne hay }(C)\end{array}$} & $50 \%$ & $15.71 \pm 2.22$ & $4.86 \pm 0.53$ & $10.85 \pm 1.95$ & $1.83 \pm 0.32^{\mathrm{a}}$ \\
\hline & $70 \%$ & $14.64 \pm 1.59$ & $3.91 \pm 0.81$ & $10.73 \pm 1.09$ & $1.85 \pm 0.24^{\mathrm{a}}$ \\
\hline \multirow{2}{*}{$\begin{array}{l}\text { Non-bird-resistant grain sorghum } \\
\text { silage }+ \text { concentrate } \\
\text { (NGS) }\end{array}$} & $50 \%$ & $16.52 \pm 1.62$ & $5.32 \pm 0.53$ & $11.2 \pm 1.43$ & $1.85 \pm 0.50^{\mathrm{a}}$ \\
\hline & $70 \%$ & $17.08 \pm 3.70$ & $6.21 \pm 2.14$ & $10.88 \pm 1.69$ & $1.93 \pm 0.40^{\mathrm{a}}$ \\
\hline \multirow{2}{*}{$\begin{array}{l}\text { Maize silage }+ \text { concentrate } \\
\text { (MS) }\end{array}$} & $50 \%$ & $19.13 \pm 1.38$ & $6.80 \pm 1.48$ & $12.33 \pm 1.46$ & $1.82 \pm 0.36^{\mathrm{a}}$ \\
\hline & $70 \%$ & $18.29 \pm 2.26$ & $6.63 \pm 1.77$ & $11.66 \pm 1.32$ & $1.61 \pm 0.41^{\mathrm{a}}$ \\
\hline \multirow{2}{*}{$\begin{array}{l}\text { Bird-resistant grain sorghum silage + } \\
\text { concentrate (BGS) }\end{array}$} & $50 \%$ & $17.19 \pm 2.20$ & $5.45 \pm 1.45$ & $11.74 \pm 0.82$ & $2.16 \pm 0.41^{\mathrm{b}}$ \\
\hline & $70 \%$ & $15.25 \pm 2.30$ & $5.12 \pm 1.35$ & $10.13 \pm 1.33$ & $1.86 \pm 0.37^{\mathrm{a}}$ \\
\hline $\begin{array}{l}\text { Forage sorghum silage }+ \\
\text { concentrate }\end{array}$ & $50 \%$ & $15.74 \pm 2.35$ & $5.06 \pm 1.51$ & $10.68 \pm 0.94$ & $1.91 \pm 0.35^{\mathrm{a}}$ \\
\hline$(\mathrm{FSS})$ & $70 \%$ & $13.82 \pm 3.11$ & $4.38 \pm 1.69$ & $9.45 \pm 1.50$ & $1.77 \pm 0.37^{\mathrm{a}}$ \\
\hline
\end{tabular}

\footnotetext{
ab Means in the same row without a common superscript differ significantly $(p<0.05)$.
} 
The sensory tenderness evaluations were apparently not sensitive enough and suggested no significant differences between samples from wethers fed different diets. It should be noted that mean shear force values of 2.16 $\mathrm{kg}$ (as reported for samples from wethers fed BGS) in any case indicates very tender meat and may not be of practical importance (Van Rensburg et al., 1992). In other experiments with similar wethers the effect of tenderness on the eating quality of lamb was negligible (Van Rensburg et al., 1992; Webb et al., 1994 \& 1999). Gullet et al. (1984) also reported that tenderness contributes less to the eating quality of lamb than in beef.

\section{Conclusion}

It was concluded that either non-bird-resistant or bird-resistant grain sorghum silage diets can be used as alternative forage sources for wethers, and that they give results similar to those obtained with maize silage diets. Similar growth responses can be achieved by finishing wethers on MS, NGS or BGS with concentrates, but wethers fed FSS at a 70\% inclusion level may grow significantly slower and yield poorer carcasses. Sorghum silage diets do not influence the sensory quality characteristics or cooking losses of loin samples from SA Mutton Merino wethers.

\section{Acknowledgements}

The authors wish to acknowledge the cooperation and assistance of the Animal Science Section, North West Agricultural Development Institute of the Department of Agricultural Development, Potchefstroom, RSA.

\section{References}

Agricultural development programme, 1986. In: Agricultural development programme for the Highveld Region. Department of agriculture and water supply, Highveld Region, Republic of South Africa. pp. 37-42.

Amsa, 1978. Guidelines for cookery and sensory evaluation of meat. American meat science association in cooperation with the national livestock and meat board, Chicago.

Boshoff, P.J., Oosthuizen, D. \& Koekemoer, L., 1980. Evaluering van gedifferensieerde energie- en stikstofaanvulling tot mieliekuilvoer vir slaglammers. S. Afr. J. Anim. Sci. 10, 1.

Bosman, M.J.C., Webb, E.C., Casey, N.H., Van Aardt, A.M. \& Steyn, H.S., 1993. Die invloed van verskillende energievlakke van die dieet op die eet- en vetkwaliteit en gaarmaakverliese van lamsvleis van verskillende rasse. J. Diet. Home Econ. 21, 107.

Bosman, M.J.C., Webb, E.C., Casey, N.H., Van Aardt, A.M. \& Silvis, N., 1994. Die invloed van hoë en mediumenergie diëte in verpilde vorm op die eet- en vetkwaliteit asook gaarmaakverliese van verskillende rasse. J. Diet. Home Econ. 22, 19.

Cramer, D.A., Barton, R.A., Shorland, F.B. \& Czochanska, Z., 1967. A comparison of the effects of white clover (Trifolium repens) and of perennial ryegrass (Lolium pereme) on fat composition and flavor of lamb. J. Agric. Sci. 69, 367.

Cross, H.R., Moen, R. \& Stanfield, S., 1978. Training and testing of judges for sensory analysis of meat quality. Food Technol. 32, 48.

Field, R.A., Williams, J.C., Ferrell, C.L., Crouse, J.D. \& Kunsman, J.E., 1978. Dietary alteration of palatability and fatty acids in meat from light and heavy weight ram lambs. J. Anim. Sci. 47, 858.

Field, R.A., Williams, J.C. \& Miller, G.J., 1983. The effect of diet on lamb flavor. Food Technol. 37, 258.

Meeske, R., Ashbell, G., Weinberg, Z.G. \& Kipnis, T., 1993. Ensiling forage sorghum at two stages of maturity with the addition of lactic acid bacterial inoculants. Anim. Feed. Sci. Technol. 43, 165.

Morrison, F.B., 1957. Feeds and Feeding. Morrison Publishing Co., Ithaca. p. 1165

Naudé, R.T., 1972. The determination of muscle, fat and bone in carcasses and cuts of young steers. S. Afr. J. Anim. Sci. 2, 35 .

Paul, P.C., Torten, J. \& Spurlock, G.M., 1981. Effect of preslaughter nutrition on palatibility and composition of lamb. In: Biological and microbiological aspects of foods (Ed J.M. Leitch), Food. Sci. Technol., Vol II, Gordon, New York. pp. 179-183.

Reyneke, J., 1967. Succulent feed intake of ewes and lambs. Proc. S. Afr. Soc. Anim. Prod. 6, 62.

Statistical Analysis Systems, 1985. SAS User's Guide: Statistics, version 5. Sas Institute Inc., Cary, NC.

Sink, J.D. \& Caporaso, F., 1977. Lamb and mutton flavor. Contributing factors and chemical aspects. Meat Sci. 1, 119.

Steele, R.G.D. \& Torrie, J.H., 1980. Principles and Procedures of Statistics. A Biometrical Approach, pp. 633. McGraw-Hill, New York. 
(C) South African Society of Animal Science

Van Rensburg, D.M.J., Zondagh, I.B., Illsley, JLL \& Naude, R.T., 1992. Sensory quality of meat from lambs fed supplementations of either calcium soaps or grain sorgum. J. Diet. Home Econ. 18, 91-96.

Webb, E.C., 1992. The influence of dietary energy levels on subcutaneous fatty acid profiles and meat quality in sheep. MSc (Agric) thesis, University of Pretoria, Pretoria, South Africa.

Webb, E. C., Bosman, M.J.C. \& Casey, N.H., 1994. Dietary influences on subcutaneous fatty acid profiles and sensory characteristics in Dorper and SA Mutton Merino wethers. S. Afr. J.Food Sci. Nutr. 6, 45.

Webb, E. C., Bosman, M.J.C. \& Casey, N.H., 1997. Influence of dietary presentation on the composition of fatty acids and sensory characteristics of meat from wethers. S. Afr. J.Food Sci. Nutr. 9, 69.

Webb, E.C., Casey, N.H. \& Bosman, M.J.C., 1999. Dietary influences on lutein pigments and carcass fat quality in wethers of different maturity types. S. Afr. J. Anim. Sci., 29, 83-91. 